DOI: https://doi.org/10.24144/2409-6857.2020.1(55).108-111

УДК 338.439

Палійчук Є.С., Павлик І.B.

\title{
ТЕОРЕТИЧНІ ПІДХОДИ ДО ФОРМУВАННЯ ОРГАНІЗАЦИЙНО-ЕКОНОМІЧНИХ МЕХАНІЗМІВ ПІДВИЩЕННЯ ЕФЕКТИВНОСТІ ФУНКЦІОНУВАННЯ ПІДПРИЕМСТВ СФЕРИ ХАРЧУВАННЯ
}

\begin{abstract}
В статті розглянуто основні теоретично можливі важелі впливу на ефективність функціонування підприємств сфери харчування. Ресторанний бізнес є одним із базових у колі підприємств середнього та малого бізнесу. 3 огляду на важкі умови функціонування економіки під час пандемії та військових операцій на Сході Украйни є вкрай важливим підтримувати та розвивати сферу харчування. Для вченихекономістів відкривається нова проблематика досліджень. У даній науковій роботі також опановано попередній досвід досліджень за темою ресторанного бізнесу та розроблені висновки та рекомендації щодо подальшого розвитку підприємств галузі харчування.
\end{abstract}

Ключові слова : ефективність, ресторанний бізнес, обслуговування населення, сфера харчування.

Постановка проблеми. Актуальною темою для дослідження $є$ розвиток та важелі впливу на ефективність функціонування підприємств ресторанного бізнесу. Цей вид господарської діяльності належить до галузі обслуговування населення i тісно пов"язаний 3 готельми комплексами, туризмом та розвитком рекреації області або регіону. Внаслідок проведеного дослідження отримаємо нові рекомендації щодо підвищення ефективності діяльності підприємств харчування в нових економічних умовах розвитку економіки України.

Аналіз останніх досліджень і публікацій. Проблеми та шляхи розвитку галузі харчування описані та досліджені багатьма українськими вченими-економістами, зокрема : організація та моделювання процесів розвитку готельноресторанного бізнесу досліджена І.В. Савельєвою [1], Ощипок I.M._описав інноваційні ресторанні технології [2], Воронюк Т.А. розкрила у своїх працях механізм управління конкурентоспроможністю ресторанного бізнесу [3], питання організації ресторанного бізнесу висвітлює закордонний автор Денні Меєр [4] , Селютін Сергій опрацьовує проблеми стратегічного управління підприємствами ресторанного бізнесу [5] та багато інших.

Формулювання цілей статті. Основним завданням даної наукової роботи $є$ визначення теоретично можливих шляхів впливу на

(C) Палійчук Є.С., к. е. н., доц., доцент кафедри економічної теорії, ДВНЗ "Ужгородський національний університет", м.Ужгород, Україна, E-mail: evgeniya.palyjchuk@uzhnu.edu.ua

Павлик I.B., аспірант, ДВНЗ "Ужгородський національний університет" м.Ужгород, Україна, E-mail: igorpavlik14@gmail.com ефективність функціонування підприємств ресторанного бізнесу.

Опис основного матеріалу дослідження 3 повним обгрунтуванням отриманих наукових результатів.

Підприємства галузі харчівання та ресторанного бізнесу функціонують в умовах постійної трансформації ринкових відносин, високої конкуренції, підвищення кількості фінансових та інших ризиків, ситуації нестабільності і невизначеності. Ресторанний бізнес, який тісно пов"язаний 3 готельним, $€$ базовою складовою частиною туристичної сфери, швидко розвивається. Підприємствам ресторанного бізнесу доводиться приймати управлінські рішення, в тому числі і фінансові, за умов системної кризи національної економіки. В багатьох випадках виникають гострі проблемні ситуації, для нейтралізації та вирішення яких необхідно зрозуміти першопричини виникнення економічних та фінансових ризиків, фактори впливу та шляхи їх усунення. Незадовільний сучасний стан української інфраструктури, іiі нерозвиненість, а також промислова орієнтація 3 боку держави стали причиною відсутності сталого розвитку підприємств сфери надання послуг, зокрема підприємств готельного та ресторанного бізнесу.

$\mathrm{y}$ попередніх дослідженнях ми визначили низку проблем, які гальмують ефективність функціонування підприємств ресторанного бузнесу. Основні з них такі :

1. Військові дії в країні та кризові явища в соціально-економічній сфері потребують рішучих дій, а саме створення умов для збереження майна закладу і його присутності на ринку. 
2. Зниження фінансових можливостей у населення для відвідування закладів громадського харчування — це одна 3 найбільших проблем розвитку даної сфери.

3. Негативний досвід співпраці закладів ресторанного господарства 3 державними контролюючими органами .

4. Низька якість сировини, матеріальнотехнічного забезпечення є однією з причин втрати клієнтської бази підприємством.

5. Низька якість роботи підрозділів на підприємствах ресторанного господарства потребує налагодження роботи відділів маркетингу, планування, обліку та контролю, безпеки, інформаційних технологій, постачання і збуту. висновки i перспективи подальших досліджень у даному напрямку. [6.]

Слід зазначити, що за даними Управління статистики на початок 2019 року в Україні налічувався 61761 заклад тимчасового розміщування і організації харчування. У порівнянні із 2010 роком кількість закладів збільшилася на 11728 одиниць, що свідчить про позитивну тенденцію розвитку ресторанного господарства в Україні. [7]. На підприємствах на початок 2019 року працювало 268,9 тис.осіб., серед яких 214,1 тис. - наймані працівники. Обсяг реалізованої продукції (товарів, послуг) у 2018 році склав 63591,5 млн.грн.

Для розкриття сутності теоретичних підходів до підвищення ефективності діяльності підприємств сфери харчування потрібно визначити сутність категорії «ефективність» для підприємств ресторанного бізнесу.

На думку Горлачук В.В. «Теорія ефективності чітко розмежовує поняття ефекту і ефективності, розуміючи під першим результат заходу, а під другим - співвідношення ефекту і витрат, які його викликали. Принциповий взаємозв'язок між вказаними двома поняттями може бути виражений різницею умовного економічного результату та повних капітальних вкладень i, залежно від рівня господарювання, може отримувати: 1) національний рівень; 2) рівень підприємства. Якщо результати економічної діяльності перевищують витрати, то можна говорити про позитивний ефект, у протилежному випадку - про негативний ефект (збиток).» [6]

Тобто ми маємо визначити шляхи зниження витрат підприємства саме організації харчування для отримання позитивного ефекту , що відповілно буде свідчити про ефективну діяльність цього підприємства. Розрахунок економічної ефективності рекомендується робити шляхом порівняння витрат 3 економічним ефектом як грошовим вираженням результату.

Виходячи з кінцевого фінансового результату - прибутку, здійснюється оцінка господарської діяльності підприємств організації харчування . початком визначення цього показника $\epsilon$ розрахунок прибутку від виробничо-торговельної діяльності, що визначається як різниця між валовими доходами від основної діяльності (сумою реалізованих торговельних надбавок i націнок без податку на добавлену вартість) i витратами виробництва та обігу. Абсолютна сума прибутку не має достатньої повноти характеристики ефективності роботи підприємств організації харчування, тому іï слід доповнити показником рентабельності. Для аналізу ефективності роботи та характеристики кінцевого фінансового результату комерційної діяльності у ресторанному господарстві застосовується система показників рентабельності.

Товарооборот ресторанного господарства в Україні на початок 2020 року показаний у таблиці 1.

Таблиця 1

Товарооборот торгівлі та ресторанного господарства, (млн.грн.)

\begin{tabular}{|l|l|l|l|l|l|l|l|}
\hline & $\mathbf{2 0 0 5}$ & $\mathbf{2 0 1 0}$ & $\mathbf{2 0 1 3}$ & $\mathbf{2 0 1 4}$ & $\mathbf{2 0 1 6}$ & $\mathbf{2 0 1 8}$ & $\mathbf{2 0 1 9}$ \\
\hline $\begin{array}{l}\text { Оптовий } \\
\text { товарооборот } \\
\text { підприсмств }\end{array}$ & 492,5 & 993,7 & 1107,3 & 1093,3 & 1074,8 & 1221,2 & 1398,6 \\
\hline $\begin{array}{l}\text { Роздрібний } \\
\text { товарооборот } \\
\text { підприсмства }\end{array}$ & 94,3 & 280,9 & 350,1 & 405,1 & 433,1 & 464,3 & 598,3 \\
\hline $\begin{array}{l}\text { Оборот } \\
\text { роздрібної } \\
\text { торгівлі }\end{array}$ & 174,4 & 541,5 & 685,7 & 812,1 & 888,8 & 1002,3 & 1200,1 \\
\hline $\begin{array}{l}\text { Оборот } \\
\text { ресторанного } \\
\text { господарства }\end{array}$ & 7,5 & 17,9 & 21,2 & 23,5 & 22,6 & 28,3 & 33,1 \\
\hline
\end{tabular}


Аналіз даних таблиці 1. свідчить про те, що за останні 10 років оборот ресторанного господарства збільшився на 15,2 млн. грн. [8].

Для підвищення показника рентабельності підприємств організації харчування потрібно організувати систематичне вивчення попиту на кулінарну продукцію, боротися за високу якість продукції, що випускається та високу культуру обслуговування клієнтів. Ці пункти є запорукою збільшення товарообігу підприємств організації харчування, прибутків та рентабельності.

На сьогодні розвиток ринкових відносин в Україні вимагає від закладів громадського харчування активних дій 3 підвищення ефективності їх функціонування. За часів початку розвитку економічної науки проблема ефективного функціонування закладів організації харчування вийшла на перший план і залишається актуальною по сьогоднішній день. Оцінка ефективності виробничої діяльності, управлінських рішень, витрат економічних ресурсів, а також конкретні технології та засоби забезпечення ефективного функціонування вегетаріанських ресторанів становлять особливий інтерес як для вітчизняних вчених, так і для практиків, менеджерів, управлінців та власників бізнесу. Ефективність $є$ складною i багатоаспектною економічною дефініцією, яку слід розглядати, по-перше, як результативність діяльності, що визначається відношенням отриманого ефекту до витрачених ресурсів; подруге, як комплексну оцінку результатів використання всіх видів ресурсів та як міру досягнення поставлених цілей.
На підприємствах організації харчування ефективність функціонування залежить від наступних організаційно-економічних механізмів :

1. раціоналізація

використання матеріальних ресурсів ;

2. управління та організація виробничого процесу ;

3. вирішення проблеми технологічного відставання ;

4. удосконалення процесу обслуговування споживачів ;

5. використання матеріальної i нематеріальної складових системи мотивації персоналу.

Висновки i перспективи подалыших досліджень. В умовах ринкової трансформації української економіки необхідність функціонування громадського харчування як галузі господарської діяльності зберегається i викликана тим, що сільське господарство i харчова промисловість не завжди можуть виробляти продукти харчування, безпосередньо готові до вживання.

За останні роки вчені припинили досліджувати ресторанне господарство як окрему складову економіки. Тому надзвичайно актуальною та перспективною темою дослідження буде питання розвитку галузі організації харчування у комерційному та державному секторах. Важливим напрямком досліджень $є$ розкриття сутності ресторанного господарства як складової соціальної інфраструктури регіону або області.

\section{ПЕРЕЛІК ВИКОРИСТАНИХ ДЖЕРЕЛ}

1. Організація та моделювання процесів розвитку готельно-ресторанного бізнесу [Текст] : кол. монографія / [І. В. Савельєва та ін.] ; Одес. нац. мор. ун-т. - Одеса : ОНМУ, 2019. - 283 с.

2. Ощипок Ігор Миколайович. Інноваційні ресторанні технології [Текст] : підручник / І. М. Ощипок. - Львів : Вид-во Львів. торг.-екон. ун-ту, 2019. - 325 с.

3. Воронюк T. А. Формування механізму управління конкурентоспроможністю підприємств ресторанного господарства [Текст] : автореф. дис. ... канд. екон. наук : 08.00 .04 / Воронюк Тетяна Анатоліївна ; Одес. нац. акад. харч. технологій. - Одеса, 2019. - 24 с.

4. Меєр, Денні. Прошу до столу. Як працює ресторанний бізнес [Текст] / Денні Меєр ; пер. з англ. Ганна Кирієнко. - Київ : Наш формат, 2019. - 337 с.

5. Стратегічне управління підприємствами ресторанного господарства [Текст] : автореф. дис. ... канд. екон. наук : 08.00.04 / Селютін Сергій Вікторович ; Харків. держ. ун-т харчування та торгівлі. - Харків, 2019. - 24 с.

6. Горлачук В.В. Економіка підприємства. [Текст] / В.В. Горлачук, І. Г. Яненкова. : [навчальний посібник] Миколаїв : Вид-во ЧдУ ім. Петра Могили, 2010. - 344 с.

7. Статистичний збірник "Діяльність суб'єктів господарювання за 2018 рік"-електронний документ - режим доступу: http://www.ukrstat.gov.ua/druk/publicat/kat_u/2019/zb/11/zb_dsg_2018.pdf

8. Офіційний сайт Державної служби статистики України - http://ukrstat.gov.ua

\section{REFERENCES}

1. Savelieva, I.V. (2019). Organization and modeling of hotel and restaurant business development processes [Orhanizatsiya ta modelyuvannya protsesiv rozvytku hotel'no-restorannoho biznesu]. Odesa: ONMU [in Ukrainian]. 
2. Oshchypok, M. (2019). Innovative restaurant technologies [Innovatsiyni restoranni tekhnolohiyi]. Lviv [in Ukrainian].

3. Voroniuk, T. A. (2019). Formation of the mechanism of management of competitiveness of the enterprises of restaurant economy [Formuvannya mekhanizmu upravlinnya konkurentospromozhnistyu pidpryyemstv restorannoho hospodarstva]. Extended abstract of candidate's thesis. Odesa: ONTU [in Ukrainian].

4. Meyer, D. (2019). Please come to the table. How the restaurant business works [Proshu do stolu. Yak pratsyuye restorannyy biznes]. Kyiv: Nash format [in Ukrainian].

5. Seliutin, S. (2019). Strategic management of restaurant enterprises [Stratehichne upravlinnya pidpryyemstvamy restorannoho hospodarstva].. Extended abstract of candidate's thesis. Kharkiv. derzh. un-t kharchuvannia ta torhivli. Kharkiv [in Ukrainian].

6. Gorlachuk, V.V. (2010) Economics of the enterprise [Ekonomika pidpryyemstva]. My`kolayiv: Vy`d-vo ChDU im. Petra Mogy'ly [in Ukrainian].

7. Statistical collection «Activities of economic entities for 2018» [Statystychnyy zbirnyk «Diyal'nist' subyektiv $\begin{array}{llllll}\text { hospodaryuvannya } & \mathrm{za} & 2018 & \text { rik»] } & \text { (2019). } & \text { Retrieved from: }\end{array}$ http://www.ukrstat.gov.ua/druk/publicat/kat_u/2019/zb/11/zb_dsg_2018.pdf [in Ukrainian].

8. Official site of the State Statistics Service of Ukraine [Ofitsiynyy sayt Derzhavnoyi sluzhby statystyky Ukrayiny]. (n.d.). Retrieved from: http://ukrstat.gov.ua [in Ukrainian].

Отримано 25.06.2020 